\title{
Microbial quality evaluation of masa processed and sold within University of Maiduguri campus
}

\begin{abstract}
Masa is a fermented bread-like product, which is round in shape with brown colour and smooth surface made from millet, maize, or rice flour. The total bacterial aerobic plate count, coliforms, mould, yeast and staphylococcal counts of Masa were determined. Discrete colonies appearing on incubated plates were isolated and identified. The results showed that South-east of University area had the highest bacterial counts, ranging from $4.26 \times 10^{2}$ to $8.33 \times 10^{2} \mathrm{CFU} / \mathrm{g}$ and coliforms counts $\left(1.331 \times 10^{2}\right.$ to $\left.3.14 \times 10^{2} \mathrm{CFU} / \mathrm{g}\right)$. Northeast sample had the highest yeast count $\left(3.2 \times 10^{2}\right.$ to $\left.1.0 \times 10^{2} \mathrm{CFU} / \mathrm{g}\right)$. Mould count was the highest in South-west ranging from $1.03 \times 10^{2}$ to $2.331 \times 10^{2} \mathrm{CFU} / \mathrm{g}$, while staphylococcal count was high $\left(2.041 \times 10^{2}\right.$ to $\left.1.061 \times 10^{2} \mathrm{CFU} / \mathrm{g}\right)$. The result indicates that Masa contain different type of microorganism like Shigella spp, Salmonella spp, Pseudomonas $s p, E$ coli and Staphylococcus. Hence Personal and environmental hygiene is required during production of Masa to avoid food borne illnesses.
\end{abstract}

Keywords: masa, microbial load, evaluation, process sold, pathogens
Volume 6 Issue 3 - 2018

\author{
MH Badau,' Nachana'a Shadrach,' AF Ogori,'2 \\ Charles Bristone,' Joeguluba Ogori ${ }^{3}$ \\ 'Department of Food Science and Technology, University of \\ Maiduguri, Nigeria \\ ${ }^{2}$ Department of Home sciences, Federal University Gashua, \\ Nigeria \\ ${ }^{3}$ Department of Agricultural Education, Federal College of \\ Education Kontagora, Nigeria
}

\begin{abstract}
Correspondence: Badau MH, Department of Food Science and Technology, University of Maiduguri, Nigeria, Tel +23 4806 4191868 ,

Email mamudubadau@gmail.com, badau@unimaid.edu.ng
\end{abstract}

Received: January 12, 2018 | Published: June 05, 2018

\section{Abbreviations: $\mathrm{CFU}$, colony forming units; g, gramme}

\section{Introduction}

Masa is a traditional fermented snack usually prepared and consumed in Northern and some part of Western states in Nigeria. ${ }^{1}$ It can be produced from maize (Zee mays), millet (Pennisetumtyphoideum), sorghum (sorghum vulgare) and rice (Orizasativa). According to the types of cereals used in preparing Masa, we have Masa of different types such as; Masa Shinkafa, Masa Masara, Masa Gero. Masa Dawa. Good quality Masa is round in shape with brown colour and smooth surfaces. Masa is a Spanish word mostly referred to all kind of dough. ${ }^{2,3}$ It is also a popular food among Hausa and Fulani tribes of Nigeria. ${ }^{4}$

The consumption of Masa brings about some certain health benefit to consumers because it contained high calories and calcium minerals. It is also a good source of energy and fibre which helps to control appetite and prevent constipation.

Cereal grains are fruit of cultivated grasses of the monocoteledoneus family. ${ }^{6}$ Its demand for food makes it abundant in East Asia and SubSahara West Africa. Many researchers have carried out studies on fermentation of cereal product. It is noted that Masa is one of the major food that is mostly consumed by student because it is one of the common ready-to-eat food. It is also a fast food with low cost compared to other foods.

It was reported that unhygienic practices among the local food processor usually brings about the contamination of food by microorganisms. This may pose significant health effects to the consumers. In Maiduguri, the outbreak of food borne diseases due to the use of contaminated water has caused the death of many children. ${ }^{7}$ In this region of the country, cause of clean water has been advocated. Since it was known that the use of clean water for food preparation influences the outcome on the final products. This includes shelf-life stability, acceptability in terms of sensory qualities and products which pose no health hazards to the consumers. Similarly, the carelessness of the local food vendors, have also been reported. ${ }^{8}$ Carelessness in food practices such as the use of unclean utensils and equipment; raw materials selection; selling of foods in open places are potential treats and so increase risk of public health.

Therefore, there was a need to investigate the microbiological quality of Masa that is being sold within the University of Maiduguri. This also ensured and ascertained the type of foods produced and sold within the University community.

The method of preparing and selling of Masa in an open space in schools may cause contamination to foods. This contamination can also occur due to the use of unclean hands. Water, equipment and utensils during preparation. So there was need to know the types of microorganisms associated with the Masa that is being consumed by the students within the university premises to ascertain its safety.

\section{Materials and method}

\section{Study area}

Handling of foods by traditional food processors and hawkers who do not adhere to strict hygiene practices could pose a threat to public health. There is the risk of foods contaminated with pathogenic microorganisms which could lead to outbreak of food borne illnesses such as staphylococcal food poisoning, shigellosis, salmonellosis and other microbial foodborne illnesses and spoilage microorganisms. Therefore, it became necessary to sample foods from processors and hawkers for microbiological assessment. It was against this programme that this study enumerated, isolated and identified of microorganisms of significance from masa, a common convenient food processed and hawked within university of Maiduguri masa.

The study area where food samples (Masa) were collected is within different locations such as commercial area, hostel area complex area with much population because of the high demand by the student and staff quarters in the university of Maiduguri campus, Borno state. 


\section{Description of food}

Masa (Figure 1) is a fermented bread-like product, which is round in shape with brown colour and smooth surface made from Millet, maize and rice floor. It is like the "india idle" in shape used in tortilla preparation it is also consumed by all age group in Northern Nigeria, with population of about 47 million. ${ }^{9}$

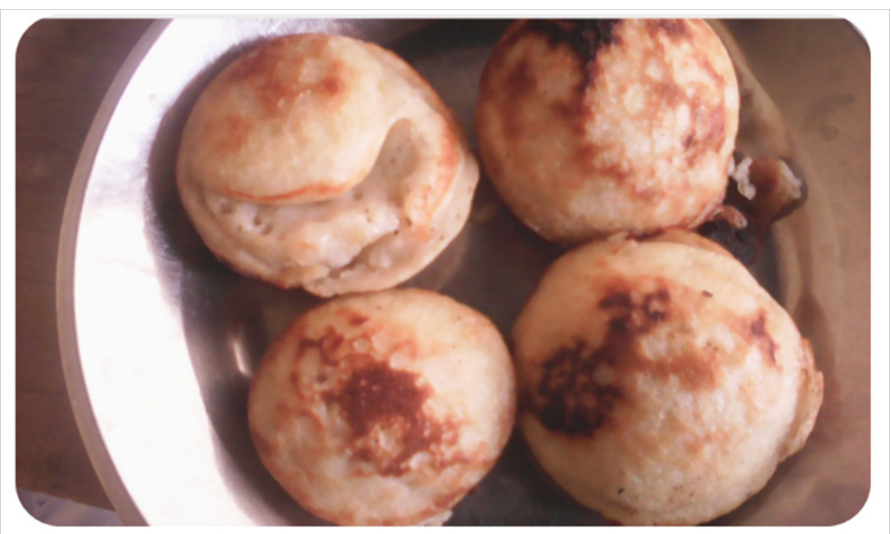

Figure I Pictures of Masa sampled from various locations within University of Maiduguri campus

\section{Samples and sampling}

A total number of 12 Masa samples were collected from vendors, 3 from each of the four cardinal point of the university of Maiduguri campus. The samples were collected in sterile containers and labelled. It was taken immediately to the laboratory for analysis.

\section{Microbiological analysis}

\section{Sterilization of materials}

All the glass wares and materials that were used for the analysis in the laboratory were washed and sterilized in a hot-air-oven at $1600 \mathrm{C}$ for one hour. ${ }^{10}$

\section{Preparation of culture media}

Culture media were prepared in accordance with the methods described by Collins and Lyne (1970), Harrigan and McCance (1976) Nkama, Badau, Chesbrough, et al. ${ }^{11-15}$

The culture media prepared were Nutrient (NA), Eosin methylene blue (EMB), Mannital salt agar (MSA), Macconkey agar (MA). potato Dextrose agar(POA) and corn meal agar. The media were prepared according to the methods described by Chesbrough. ${ }^{15}$

\section{Preparation of nutrient agar (NA)}

Nutrient agar (NA) was prepared by weighing fifty-two grams of the power and dispensing into 1liter of sterile distilled water in a conical flask and was allowed to dissolve completely by swirling. It was sterilized by autoclaving at $12 \mathrm{I}^{\circ} \mathrm{C}$ for 5 minutes at 15 pounds pressure. It was allowed to cool to a temperature of $45^{\circ} \mathrm{C}$ and poured into sterile peptic dishes and allowed to gel (solidity). The surface was dried in hot-air-oven before inoculation. ${ }^{15}$

\section{Preparation of eosine methylene blue agar (EMB)}

Eosine methylene blue (EMB) was prepared by weighing thirty six grams of EMB powder (Himedia laboratory) into Ilitre of distilled water in a clean control flask and was heated to dissolve completely. It was then sterilized by autoclaving at $121^{\circ} \mathrm{C}$ at $15 \mathrm{psi}$ pressure for 15 minutes. The culture medium was allowed to cool to $45^{\circ} \mathrm{C}$ before pouring into petri-dishes. ${ }^{15}$

\section{Preparation of mannitol salt agar (MSA)}

Mannitol salt agar (MSA) was prepared by dissolving 11 grams in 1liter of distilled water, followed by gentle heating to dissolves the medium completely and sterilized by autoclaving at $12 \mathrm{I}^{\circ} \mathrm{C}, 15$ minutes. ${ }^{15}$

\section{Preparation of macconkey agra (MA)}

MacConkey agar (MA) was prepared by weighing fifty-two grams of the powder into sterilized flask containig I liter of sterile distilled water. It was sterilized by autoclaving at $121^{\circ} \mathrm{C}, 15 \mathrm{psi}$ pressure for 15 minutes. Thereafter mixed well before pouring into petri-dishes and allowed to gel (solidity). The surface was dried in hot-air-oven before inoculation. ${ }^{15}$

\section{Preparation of potato dextrose agar (PDA)}

Potato Dextrose agar (PDA) was prepared by dissolving 39grams of media into sterilized conical flask containing 1litre of distilled water and heated to dissolve the medium completely. It was sterilized by autoclaving at $12 \mathrm{I}^{\circ} \mathrm{C} 15 \mathrm{psi}$ pressure for 15 minutes. ${ }^{15}$

\section{Preparation of corn meal agar (CMA)}

Corn meal agar was prepared by dissolving 17 grams of the power into 1 litre of sterile distilled water in conical flask and gently heated to dissolve the medium completely, then sterilized by autoclaving at $12 \mathrm{I}^{\circ} \mathrm{C} 15 \mathrm{psi}$ pressure for 15 minutes. This was allowed to cool $45^{\circ} \mathrm{C}$ before pouring into petri-dishes and allowed to solidity befor use. ${ }^{15}$

\section{Microbiological analysis}

\section{Serial dilution}

One gram of each sample of Masa was weighed and dispensed into $9 \mathrm{ml}$ of sterile distilled water as a diluent. Serial dilution was conducted by adding $1 \mathrm{ml}$ from tube one into the second test tube and mixed carefully by shaking it gently. The same procedure was made several times. ${ }^{4}$

\section{Plating, culture incubation}

A pour plate technique was used for plating the Masa culture. A triplicate of sterile petri- dishes were labelled corresponding to the number of tube containing the culture. Separate sterile pipettes was used to transfer $1 \mathrm{ml}$ of sample from the dilution tube to the corresponding petri-dishes before pouring molten nutrient agar that has been cooled to $45^{\circ} \mathrm{C}$ after sterilization. This was swirled gently to mix the agar and allowed to solidify before it was incubated at $37^{\circ} \mathrm{C}$ for 24 hours. ${ }^{15}$

\section{Viable cell count}

The total plate count for the growth of bacterial colonies on plates was observed by colony counter to count and record the number of colonies on each plate. The actual number of bacterial colonies was calculated as colony forming unit $(\mathrm{CFU} / \mathrm{ml})$ as described by Harriggan and McCance. ${ }^{16}$ 


\section{Identification of bacteria}

Gram staining techniques: A smear of the specimen was made on slide with a clean glass rod. The film was air dried by waving it over a bunsen flame. The slide was placed on a rack over a sink, cover, smear with crystal violet (the Preioxital stains) reagent and allowed to remain for one minute. The stain was washed off by holding the slide at an angle downwards, and then flooded with iodine solution acting as a mordant. The slide was placed back on the rack and cover with fresh Lugols iodine solution; allowed to react for 1minute. The lugols iodine was pour off and rinsed with gentle running tap water. The slide was also hold in a tilled position and pour acetone reagent slowly until no more dye runs out of the smear to decolourise it. The slide was thoroughly washed with water under gentle running tap water. The whole slides were covered with a counter stain neutral red and allow to reaact for 1 minute. The slide was rinsed slowly under running tap water and blotted with filter paper and allowed to dry in air. A drop of oil immersions was placed in the stained smear and examined using the immersion lens (x100 objective) of a microscope.

Isolation and identification of microorganisms: Microorganisms were isolated and identified based on cultural and morphological characteristics using method described by Harrigan et al. ${ }^{16}$ Biochemical tests such as catalase test, coagulase test, indole test, methyl red (MR) test, Voges-Proskauer test, citrate utilization test, urease test and oxidase test were carried out as described by Harrigan $\&$ McCance,${ }^{16}$ and Cheesbrough. ${ }^{15}$ Results obtained from these tests were compared with literature standards using diagnostic tables showing the biochemical reactions identifying many genera and species of bacteria. ${ }^{17}$

\section{Data analysis}

The data obtained were analysed to find the mean using Microsoft word excel (2010).

\section{Results and discussion}

The result of microbial load of Masa obtained from four cardinal points within university of Maiduguri campus is shown in Table 1. The total bacterial count ranged from $4.26 \times 10^{2}$ to $6.39 \times 10^{2}, 6.80 \times 10^{2}$ to $7.46 \times 10^{2}, 4.27 \times 10^{2}$ to $5.6 \times 10^{2}$ and $5.16 \times 10^{2}$ to $8.33 \times 10^{2} \mathrm{CFU} / \mathrm{g}$ of masa from North West, North East, South West and South east of University of Maiduguri campus, respectively. Coliform counts of masa from North West ranged from $2.40 \times 10^{2}$ to $2.77 \times 10^{2} \mathrm{CFU} / \mathrm{g}$, North East masa had coliform count of $1.33 \times 10^{2}$ to $2.66 \times 10^{2} \mathrm{CFU} / \mathrm{g}$. Coliform counts of masa collected from South West and South East ranged from $1.71 \times 10^{2}$ to $2.35 \times 10^{2}$ and $1.39 \times 10^{2}$ to $3.41 \times 10^{2} \mathrm{CFU} / \mathrm{g}$, respectively.

The mould count of masa obtained from North West ranged from $1.10 \times 10^{2}$ to $2.18 \times 10^{2} \mathrm{CFU} / \mathrm{g}$, North East masa ranged from $1.16 \times 10^{2}$ to $2.04 \times 10^{2} \mathrm{CFU} / \mathrm{g}$, South West had mould count of $1.20 \times 10^{2}$ to $2.33 \times 10^{2} \mathrm{CFU} / \mathrm{g}$ and South East masa had $1.15 \times 10^{2}$ to $2.17 \times 10^{2} \mathrm{CFU} / \mathrm{g}$ of mould count. The yeast count of masa obtained from North West, North East, South West and South East ranged from $1.01 \times 10^{2}$ to $3.02 \times 10^{2}, 1.15 \times 10^{2}$ to $3.21 \times 10^{2}, 1.06 \times 10^{2}$ to $2.12 \times 10^{2}$ and $1.04 \times 10^{2}$ to $3.01 \times 10^{2}$, respectively. Whreeas, staphylococcal count of masa from North West of university of Maiduguri campus ranged from 1.10x $10^{2}$ to $2.01 \times 10^{2}$, North East, ranged from $1.08 \times 10^{2}$ to $2.04 \times 10^{2}$, South West, ranged from $1.15 \times 10^{2}$ to $2.04 \times 10^{2}$ and South East, ranged from $1.06 \times 10^{2}$ to $1.18 \times 10^{2} \mathrm{CFU} / \mathrm{g}$.

Table I Mean value of microbial load of Masa samples from different locations from university of Maiduguri (expressed as cfu/g)

\begin{tabular}{|c|c|c|c|c|c|}
\hline Location & Total bacteria & Coliforms & Coliforms & Yeast & staphylococcus \\
\hline & Count & Count & Count & Count & Count \\
\hline \multicolumn{6}{|c|}{ North West } \\
\hline NWUI & $4.26 \times 10^{2}$ & $2.27 \times 102$ & $1.03 \times 10^{2}$ & $1.52 \times 10^{2}$ & $1.10 \times 10^{2}$ \\
\hline NWU2 & $4.86 \times 10^{2}$ & $2.77 \times 102$ & $2.18 \times 10^{2}$ & $1.01 \times 10^{2}$ & $2.01 \times 10^{2}$ \\
\hline NWU3 & $6.39 \times 10^{2}$ & $2.40 \times 102$ & $1.10 \times 10^{2}$ & $3.02 \times 10^{2}$ & $1.11 \times 10^{2}$ \\
\hline \multicolumn{6}{|l|}{ North East } \\
\hline NEUI & $6.80 \times 10^{2}$ & $2.66 \times 102$ & $1.30 \times 10^{2}$ & $3.21 \times 10^{2}$ & $1.08 \times 10^{2}$ \\
\hline NEU2 & $7.46 \times 10^{2}$ & $1.33 \times 102$ & $1.16 \times 10^{2}$ & $1.15 \times 10^{2}$ & $1.12 \times 10^{2}$ \\
\hline NEU3 & $6.80 \times 10^{2}$ & $2.10 \times 102$ & $2.04 \times 10^{2}$ & $2.13 \times 10^{2}$ & $2.04 \times 10^{2}$ \\
\hline \multicolumn{6}{|l|}{ South West } \\
\hline SWUI & $4.27 \times 10^{2}$ & $1.71 \times 102$ & $2.14 \times 10^{2}$ & $1.08 \times 10^{2}$ & $2.03 \times 10^{2}$ \\
\hline SWU2 & $4.53 \times 10^{2}$ & $2.35 \times 102$ & $1.20 \times 10^{2}$ & $1.06 \times 10^{2}$ & $1.15 \times 10^{2}$ \\
\hline SWU3 & $5.60 \times 10^{2}$ & $2.10 \times 102$ & $2.33 \times 10^{2}$ & $2.12 \times 10^{2}$ & $2.04 \times 10^{2}$ \\
\hline \multicolumn{6}{|l|}{ South East } \\
\hline SEUI & $7.20 \times 10^{2}$ & $3.41 \times 102$ & $1.15 \times 10^{2}$ & $1.20 \times 10^{2}$ & $1.12 \times 10^{2}$ \\
\hline SEU2 & $8.33 \times 10^{2}$ & $1.52 \times 102$ & $2.17 \times 10^{2}$ & $3.01 \times 10^{2}$ & $1.06 \times 10^{2}$ \\
\hline SEU3 & $5.16 \times 10^{2}$ & $1.39 \times 102$ & $2.03 \times 10^{2}$ & $1.04 \times 10^{2}$ & $1.18 \times 10^{2}$ \\
\hline
\end{tabular}

KEY: NWU, North west university; NEU, North east university; SWU, South west university; SEU, South east university 
Table 1 above presents the results of the mean value of microorganisms of Masa sample from different locations in the University of Maiduguri. The result revealed the total bacterial count from south east of $8.33 \times 10^{2}$ had the highest bacterial load count while Northwest had the lowest bacterial count of $4.26 \times 10^{2}$. Colifonns count had the highest count of $3.14 \times 10^{2}$ from south-east and the lowest count at $1.33 \times 10^{2}$ from North-east. Yeast count which is $3.2 \mathrm{Ix} 10^{2}$ had the highest count. While $1.01 \times 10^{2}$ from north- west had the lowest count. Mould count $2.33 \times 10^{2}$ had the highest count from south west. Staphylococcus count from north-east with $2.04 \times 10^{2}$ had the highest count while south-east had the lowest count of $1.06 \times 10^{2}$.

The result obtained from the analysis showed that bacterial count from south-east had the highest count compared to others, which could be as a result of poor processing method, poor hygiene practice, improper and unhygienic handling of the product, bad sanitation operations and use of unclean utensils. This agrees with the fact that immense microbial contamination of food is linked to poor post processing handling practices ${ }^{18}$ and the Masa from North-west had the lowest bacterial count and it could be as a result of the differences in processing practices.

The presence of coliforms from south-east is high compared to other locations and it can be as a result of unhygienic practices related to feacal contamination, the great increase in the count could be as the location of the retail outlet in which basically heavy contamination occurs. This finding suggests food was exposed to feacal or sewage contamination through the use of contaminated water or contamination from the unsanitary environment, equipment and carriage. ${ }^{4}$

Yeast count is indicated to be the highest from North-east due to direct exposure to air, product is opened as often as the customer's demand and also the handling processes by the vendors, ${ }^{13}$ started that the dusty unhygienic environment coupled with the poor handling by vendors are factors contributing to the high microbial load.
Masa from North-west is lower in yeast count and it could be due to environmental factors.

Mould count is high from south-west which could be as a result of the environmental factors due to dust and open air; therefore, enviromental contaminants have also been implicated as food borne pathogens. ${ }^{1}$ North-west had the lowest count which indicates that the environment where the Masa is processed is safer.

Staphylococcus had the highest count from North-east which could be as a result of contaminants from personnel through dirty hands, cloths and utensils that comes in contact with the food. Staphvlococcus is common organisms found in all individuals and expelled from the respiratory tract, nose, mouth, clothing, hand and skin. ${ }^{1}$

From the result obtain in Table 2 salmonlla is known as a pathogen that causes typhoid, fever and food poisoning. ${ }^{19}$ Pseudomonas $s p$ is an opportunistic pathogen that cause bacteremia and gastrointestinal infections ${ }^{20}$ shigella is a pathgen and its presence has been contributed to unhygienic practices related to faecal contamination. ${ }^{21,22} E$ coli is an indicator of postprocessing contamination. Staphylococcus is common organisms found in all individuals and expelled from the respiratory track, nose, mouth, clothing, hand and skin. Aboloma have reported that the incidence of staphylococcus in food is an indication of environment and human contamination. It is a pathogen of public health importance.

The percentage occurenrance of microorganisms for "Masa" is shown in Table 3. Salmonella, Shigella and Rhizopus Oryza had $37.5 \%$ occurrence in "Masa" but the occurrence of S. aureus, E coli, Pseudomonas, Candida albicas, Saccharomyce cerevisie, is $25 \%$ in Masa. The occurrence of all this microorganism is a result of contamination from air could be as a result of unhygienic practices and poor sanitation in and around the environment. ${ }^{23-25}$ The dusty, unhygienic environment coupled with the poor handling by vendors are factors contributing to the high microbial load.

Table 2 Morphological and biochemical identification of microbial isolate from "Masa"

\begin{tabular}{|c|c|c|c|c|c|c|c|c|c|c|c|c|}
\hline $\mathbf{S} / \mathbf{N}$ & $\begin{array}{l}\text { Morphological } \\
\text { characteristics }\end{array}$ & $\begin{array}{l}\text { Gram } \\
\text { reaction }\end{array}$ & Motility & Co & $\mathrm{Ca}$ & Me & In & Ur & Cit & ox & $V p$ & $\begin{array}{l}\text { Organisms } \\
\text { isolate }\end{array}$ \\
\hline I & $\begin{array}{l}\text { Smooth cream opague } \\
\text { colonies with entire edges }\end{array}$ & + Cocci & - & + & + & + & - & + & - & - & - & Staphylococcus \\
\hline 2 & Smooth pink & $-\operatorname{rod}$ & + & - & + & - & + & - & - & - & - & F. coli \\
\hline 3 & $\begin{array}{l}\text { circular colonies that } \\
\text { ferment lactose } \\
\text { Large grey white mucoid } \\
\text { colonies }\end{array}$ & - rod & - & + & + & - & - & - & + & + & - & $\begin{array}{l}\text { Pseudomon } \\
\text { as Spp }\end{array}$ \\
\hline 4 & $\begin{array}{l}\text { Large flat } \\
\text { spreading colonies } \\
\text { with distint smell }\end{array}$ & -rod & + & - & + & + & - & - & + & + & + & $\begin{array}{l}\text { Salmonella } \\
\text { Spp }\end{array}$ \\
\hline 5 & $\begin{array}{l}\text { Pele colour non lactose } \\
\text { fermenting } \\
\text { colonies }\end{array}$ & $-\operatorname{rod}$ & - & + & + & + & - & - & + & - & - & Shigella \\
\hline
\end{tabular}

Key: Co, Cogulatase; Ca, Catalase; Me, Methyl red; In, Indole test; Ur, Urease; Cit, Citrate; Ox, Oxidase;Vi,Voges-proskauer; (+), $90 \%$ or more positive; No reaction 
Table 3 The percentage occurenrance of microorganisms for "Masa"

\begin{tabular}{|c|c|c|c|c|c|c|}
\hline $\mathbf{S} / \mathbf{N}$ & $\begin{array}{l}\text { Organisms } \\
\text { isolate }\end{array}$ & $\begin{array}{l}\text { Samp } \\
\text { locati }\end{array}$ & & & & \\
\hline & & N.W & N.E & S.W & S.E & $\begin{array}{l}\% \\
\text { Occuence }\end{array}$ \\
\hline I & S.aureus & - & + & - & + & 25 \\
\hline 2 & Salomonella & + & + & + & - & 37.5 \\
\hline 3 & E.coli & + & - & - & + & 25 \\
\hline 4 & Shigellia & + & + & + & - & 37.5 \\
\hline 5 & Pseudomona & - & + & - & + & 25 \\
\hline 6 & Candida albicas & - & + & + & - & 25 \\
\hline 7 & $\begin{array}{l}\text { Saccharomyce } \\
\text { cerevisie }\end{array}$ & + & - & - & + & 25 \\
\hline 8 & Rhizopusoryza & - & + & + & + & 37.5 \\
\hline
\end{tabular}

Keys: (+), Present; (-), absent; N.W, North-west; NE, North-east; SW, Southwest; S.E, South-east

\section{Conclusion}

The analysis of Masa for the isolation and identification of microorganisms has shown that there is higher amount of microbial contaminants in Masa due to the way of distribution, use of contaminated water, dirty utensils, the method of service and display in an open air which may be potentially pathogenic to human being and could be a health safety problem.

\section{Acknowledgements}

Technical assistance rendered by laboratory staff of the Department of Food Science and Technology is gratefully acknowledged.

\section{Conflict of interest}

Author declares that there is no conflict of interest.

\section{References}

1. Aboloma RI. Microbiological analysis of bread samples from bakery to sale points in ado-Ekiti, Ekiti State, Nigeria. Biol Environ Sci j Tropics. 2008;5:77-81

2. Ayo JA, Agu H, Famoriyo AF. Effect of differet cereal on quality of Masa. Pakistan J Nutr. 2008;7(4):533.

3. Bacteriological Analytical Manual. 6th ed. In: Arlington VA, editor Association of official Analytical chemists foor FDA. Washington; 1992. p. 191-198.

4. Bukar AI, Uba A, Oyeyi TI. Occurrence of some entero pathogenic bacteria in some minimally and fully processed ready to eat foods in Kano metropolis, Nigeria. African Journal of Food Science. 2009;4(2):032036.

5. Corleone J RDN. Nutritional information on Masa flour vs whole corn. 2015.

6. Nkama I, Malleshi NG. Production and nutritional quality of traditional Masa from mixture of rice, pearl, millet, cowpea and groundnut. Food nutritional Bull. 1998:19(4):336-373.
7. Shittu OB, Olaitun JO, Amusa TS. Physico-chemical and bacteriological analysis of water used for drinking and swimming purpose. Afr J Biochemistry Res. 2008;11(3):285-290.

8. Shamsuddeen U, Ameh JB. Survey on the possible critical control point during the production of Balangu in Kano. Bayero $J$ of pure and App Science. 2008;1(1):76-79.

9. Nkama 1. Studies on improving the nutritional qualitv of Masa. Traditional fermented cereal based food. A report to the unite nations University. Central food Technological Research (CRTRI), India; 1993.

10. Raafat El-Gewery M. Sterilization in biotechnology. Annual Review. 2008; 14:1-475.

11. Nkama I, Malleshi NG. Production and nutritional quality of traditional Masa from mixture of rice, pearl, millet, cowpea and groundnut. Food nutritional Bull. 1998:19:336-373.

12. Nkama I. Production- utilization and research properties of traditional food preparation of pearl millet in nigeria. In: Emechebe arm Ikwelle MC, Ajayi O, Aminu Kano M, Avaso AB, editors. Agricultural proceeding of pre-season national coordination and planning meeting of the national coordinated programme in peral millet Maiduguri. 1998:21-24

13. Oranusi S. Microbiological Safety evaluation of street vended ready to eat fruits sold in Ota, Ogun State, Nigeria. Int J Res Biology science. $1993 ; 1: 27-32$.

14. Merriam AM, Aderoju ST. Food safety knowledge and practices of street food vendors in the city of Abeokuta, Nigeria food control. 2008;19(4):396-402.

15. Cheesbrough M. Distinct laboratory practice in tropical countries, part 2. Cambridge University Press, UK; 2006:62-69.

16. Harrigan WF, McCance ME. Laboratory methods in food and diary microbiology 8th ed. London: academic press inc; 1990. p. 286-303.

17. Cowan S, Steel KY. Diagnostic tables for the common medical bacteria Journal of Hygiene Cambridge. 1961;59:357-365.

18. Clayton DA, Griffith DJ, Price P, et al. Food handlers beliefs and selfreported practices. International journal of Envoronmnetal Health Research. 2002;12(1):25-39.

19. Ekperigin IE, Nagaraja KV. Microbial foodborne pathogens. Salmonella vet clin North Am Food Anim Pract. 1998;14:17-29.

20. Kim KY, Kimb HT, Kim D, et al. Distribution characteristics of airborne bacteria and fungi in the feedstuff- manufacturing factories. $J$ Hazard Mata. 2009;69:1054-1060.

21. Fredlund HE, Back LS, Tornquist E. Water-melon as a vehicle of transmission of shigellosis. Scandinaavian. 1987;19(2):219-221.

22. Beuchat LR. Pathogenic microorganisms associated with fresh produce. J food prof. 1996;59(2):204-216.

23. Compendium of methods for the microbiological examination of foods. In: Carl Vanderzant, Don FS, edtiors. Washington DCP; 1992:593-603.

24. Rudiger KV. To the memory of Dr. Ursula (uschi) Greinert-Byer. Drukerei Franz Hansen, Bergisan Gladbach; 2002:70-90.

25. Ifayalways G. Hausa Food (f):6:20pm on Aug 12.J.M.Jay. Modern Food Microbiology. 6th ed. Aspen publishers Inc. Gaithersburg, Maryland; 2000:60-89. 